\title{
Harm-reduction goals and safer-drinking strategies among individuals attending a new drop-in center
}

\author{
Véronique S Grazioli ${ }^{1,2^{*}}$, SE Collins², S Paroz ${ }^{1}$, C Graap ${ }^{1}$, J-B Daeppen ${ }^{1}$ \\ From INEBRIA 12th Congress, \\ Atlanda, GA, USA. 24-25 September 2015
}

\section{Background}

Although socially marginalized individuals with alcohol-use disorders (AUDs) experience severe alcoholrelated harm, few enter treatment. [1,2] Developing innovative, tailored interventions is therefore important to addressing this population needs. The Harm Reduction Treatment - Brief Intervention (HaRT-BI), designed to elicit self-generated harm-reduction goals and discuss safer-drinking strategies [3], was adopted for a new drop-in center that allows drinking in Switzerland. This study aimed to qualitatively document participants' self-generated harm-reduction goals and safer-drinking strategies endorsement at the HaRT-BI baseline session.

\section{Material and methods}

Participants $(\mathrm{N}=78 ; 16.7 \%$ female; mean age $=38)$ were socially marginalized individuals with AUDs participating in a larger study evaluating a new facility attendance and subsequent drinking outcomes. At baseline, study interventionists elicited participants' harm-reduction goals with an open-ended question ('What would you like to see happen for you in the next 4 weeks?') and provided participants with a list of 12 safer-drinking strategies (e.g., taking vitamins, counting drinks). (3) Content analysis was used to categorize the goals and strategies participants endorsed.

\section{Results}

Seventy-six participants (97.4\%) generated and endorsed at least one goal $(M d n=2.1, I Q R=2)$ and one strategy

\footnotetext{
* Correspondence: graziv@u.washington.edu

'Department of Community Medicine and Health, Alcohol Treatment Center, Lausanne University Hospital, Lausanne, Switzerland

Full list of author information is available at the end of the article
}

$(M d n=3, I Q R=1)$. The 5 most highly endorsed goals categories included drug and alcohol-related goals (e.g., reducing, connecting with treatment), basic-need goals (i.e., searching housing), health-related goals (i.e., improving health), and quality-of-life goals (i.e., engaging in meaningful activities). Changing manners of drinking (e.g., spacing drinks) was the most highly endorsed strategy type, followed by buffering the effects of alcohol on the body (e.g., eating) and reducing drinking.

\section{Conclusions}

Most participants did generate and endorse harm-reduction goals and safer-drinking strategies, which replicated US findings $[4,5]$. These results suggest that HaRT-BI may be used to help these individuals set harm-reduction goals and safer-drinking strategies. Future research is needed to test HaRT-BI effectiveness in decreasing alcohol outcomes.

\section{Acknowledgements}

This study was funded by the Commission de promotion de la santé et de la lutte contre les addictions (CPSLA), Switzerland.

\section{Authors' details}

'Department of Community Medicine and Health, Alcohol Treatment Center, Lausanne University Hospital, Lausanne, Switzerland. 'Department of Psychiatry and Behavioral Sciences, Harborview Medical Center, University of Washington, Seattle, WA, USA.

Published: 24 September 2015

\section{References}

1. Wenzel SL, Audrey Burnam M, Koegel P, Morton SC, Miu A, Jinnett KJ, et al: Access to inpatient or residential substance abuse treatment among homeless adults with alcohol or other drug use disorders. Med Care 2001, 39(11):1158-69, [Research Support, U.S. Gov't, P.H.S.].

2. Hwang SW, Wilkins R, Tjepkema M, O'Campo PJ, Dunn JR: Mortality among residents of shelters, rooming houses, and hotels in Canada: 11 year follow-up study. BMJ 2009, 339. 
3. Collins SE, Duncan MH, Smart BF, Saxon AJ, Malone DK, Jackson TR, et al: Extended-release Naltrexone and Harm Reduction Counseling For Chronically Homeless People with Alcohol Dependence. Substance Abuse 2014, 29:0.

4. Collins SE, Grazioli VS, Torres NI, Taylor EM, Jones CB, Hoffman GE, et al: Qualitatively and quantitatively evaluating harm-reduction goal setting among chronically homeless individuals with alcohol dependence. Addict Behav 2015, 8(45C):184-90.

5. Grazioli VS, Hicks J, Kaese G, Lenert J, Collins SE: Safer-drinking strategies used by chronically homeless individuals with alcohol dependence. I Subst Abuse Treat 2015.

doi:10.1186/1940-0640-10-S2-019

Cite this article as: Grazioli et al:: Harm-reduction goals and safer-

drinking strategies among individuals attending a new drop-in center. Addiction Science \& Clinical Practice 2015 10(Suppl 2):O19.

\section{Submit your next manuscript to BioMed Central} and take full advantage of:

- Convenient online submission

- Thorough peer review

- No space constraints or color figure charges

- Immediate publication on acceptance

- Inclusion in PubMed, CAS, Scopus and Google Scholar

- Research which is freely available for redistribution

Submit your manuscript at www.biomedcentral.com/submit 